\title{
Study of honey according to botanical origin and physicochemical parameters in the Biobío Region, Chile
}

\author{
Sofia García $^{1}$, J. Max Troncoso ${ }^{2,3 *}$, and Mauricio Rondanelli-Reyes ${ }^{2}$ \\ ${ }^{1}$ Universidad Santo Tomás, Departamento de Ciencias Básicas, Mendoza 120, Los Ángeles, Chile. \\ ${ }^{2}$ Universidad de Concepción, Escuela de Ciencias y Tecnologías, Departamento de Ciencias y Tecnología Vegetal, Juan Antonio Coloma 0201, \\ Los Ángeles, Chile. "Corresponding author (josemaxtroncoso@gmail.com). \\ ${ }^{3}$ Universidad Adventista de Chile, Facultad de Educación y Ciencias Sociales, Camino a Tanilvoro km 12, Chillán, Chile.
}

Received: 16 June 2020; Accepted: 13 August 2020; doi:10.4067/S0718-58392020000400675

\begin{abstract}
The physicochemical properties of honey vary considerably depending on the nectar sipped by Apis mellifera bees because these characteristics are determined by environmental, geographical, and vegetational conditions in foraging areas. The aim of this study was to characterize types of honey from the Biobío Province in the Biobío Region, Chile, according to its botanical origin and physicochemical and microbiological characteristics, and thus contribute to increased knowledge about honey in the region. A total of 11 samples from different communes within the region were analyzed. Physicochemical parameters such as moisture, insoluble solids, ashes, electrical conductivity, $\mathrm{pH}$, and hydroxymethylfurfural were determined, and the presence of coliforms and Escherichia coli was evaluated. Two places of provenance were characterized as monofloral of introduced plant species: the M11 sample of Melilotus indicus and the M1 sample of Echium vulgare. One place of provenance (M6 sample) was characterized as monofloral of Eucryphia glutinosa, species endemic to Chile. All types of honey complied with the physicochemical standards established by national and international food safety regulations, and none had any signs of coliforms or E. coli. Results showed that there are new types of honey in the region that meet all the required parameters; in addition, they provide a comparison of plant species that are unique in the world. This demonstrates the potential of these types of honey for national and international marketing.
\end{abstract}

Key words: Apis Mellifera, Eucryphia glutinosa, melissopalynology, monofloral, physicochemical.

\section{INTRODUCTION}

In recent years, the demand for honey has shown a steady increase mainly due to its natural origin and sweetness, which is the result of a high sugar content mostly obtained from the nectar sipped by bees from flowers; honey is also attributed with various medicinal properties (Montenegro et al., 2009; Navarrete et al., 2016; Barrera, 2017; Bridi and Montenegro, 2017; Velásquez and Montenegro, 2017). Similarly, the use of bees as biomarkers of the health status of the environment has recently been promoted due to their sensitivity to climate change and environmental pollutants. The evidence for this is the colony collapse disorder and the emergence of new diseases, which have caused significant variations in the honey market (Barrera, 2017). The decline in bee products in recent years is due to colony collapse disorder, which has generated an upward price trend (Majewski, 2017). World honey consumption has increased markedly in the European Union and the USA (Popp et al., 2018; Ferrier et al., 2018). Demanding international markets have established strict quality standards and have enhanced those products with certain characteristics mainly related to food safety. Therefore, regulations have been developed that allow quality certification of these honey products (Montenegro et al., 2008). 
Since 2005, the Chilean Standards Division of the National Normalization Institute (INN) has established standards to carry out the physicochemical characterization of national honey (INN, 2013). It provides beekeepers with the basic knowledge to position their honey in international markets, which are increasingly reluctant to receive products without guarantees as to their origin and composition. The possibility of determining the pollen content of honey by melissopalynology contributes added value to the honey product and differentiate it in the market (Montenegro et al., 2008). Although the honey certification process has become more important in the beekeeping sector because it is considered an essential stage for honey marketing (Schifani et al., 2016), this process is not associated with the knowledge of the analyses to be performed on the product or the usefulness of the results of these analyses on the final product. This point is still widely unknown to beekeepers.

Therefore, the concern for research on this topic led to the present study. The objective was to analyze and characterize honey through palynological, physicochemical, and microbiological analyses in a region where the composition of honey is not sufficiently known and to establish if there were unique characteristics in the locations under study.

\section{MATERIALS AND METHODS}

The study area consisted of a geographical area $\left(37^{\circ}-38^{\circ} \mathrm{S} ; 71^{\circ}-72^{\circ} \mathrm{W}\right)$ in the Biobío Province, Biobío Region, Chile. A total of 11 honey samples obtained from different communes in the established area were analyzed (Figure 1). All samples were obtained between January and March 2013.

Vegetation in the Biobío Province is mainly characterized by vegetation units of the sclerophyll forest in sandy areas, border deciduous forest, high-Andean Biobío forest, high-Andean forest steppe, high-Andean deciduous forest of Chillán, and high-Andean deciduous forest of the La Araucanía Region. Some species of fruit trees commonly grown in the province are also present and whose pollen grains are frequently found in national honey (Navarrete et al., 2016).

Figure 1. Map of the places of provenance of the samples under study by commune in the Biobío Province, Biobío Region, Chile.

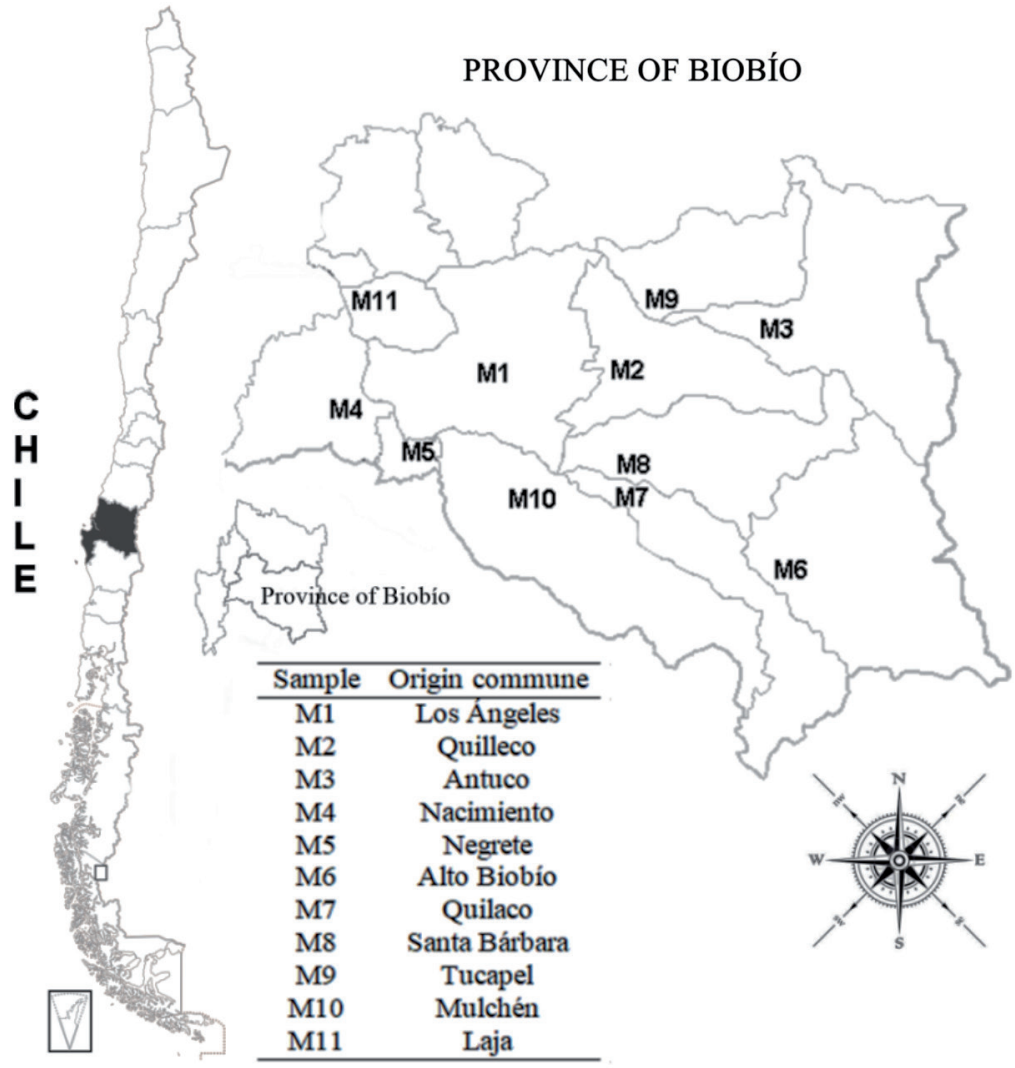




\section{Determination of botanical origin by melissopalynological analysis}

The palynological analysis of the honey samples followed the acetolysis method described by Faegri and Iversen (1989) and according to the current national standard NCh2981Of.2007 (INN, 2013). This technique consists in performing acid hydrolysis to a 40-g sample of honey to eliminate organic remains of the honey (wax, sugars, insect parts, etc.), except for the pollen grains that can resist this procedure. A mixture of pure acetic anhydride and concentrated sulfuric acid in a 9:1 ratio was applied. Once the process was completed, only the outer layer (exin) of the pollen grains remained, allowing the identification of each species.

The pollen count was performed under an optical microscope (10X and 40X) and at least 1200 pollen grains per preparation were counted. The botanical determinations of the polymorphs were made using literature that is specific to Chile, as described by Heusser (1971) and Markgraf and D'Antoni (1978). For species of exotic origin, the polynotheca of the Palynology and Plant Ecology Laboratory of the Universidad de Concepción was used. All the samples were later classified according to the Chilean standard NCh2981, whereby those types of honey that mainly recorded pollen from one species, including a percentage equal to or greater than $45 \%$ in this pollen composition, were considered monofloral types of honey. Bifloral types of honey were established as those in which the pollen composition was primarily from two species with no less than 50\% and the difference between the two was not greater than 5\%. Finally, polyfloral types of honey were those made from the nectar of various species and in the pollen content in their chemical composition for any of them did not reach a percentage equal to or greater than $45 \%$.

\section{Determination of physicochemical parameters}

Moisture. The procedure established by the National Normalization Institute using the standard NCh3026Of.2006 (INN, 2013) was followed to determine moisture. The amount of water contained in each sample was measured by placing 50 $\mathrm{mL}$ of honey without impurities in a volumetric flask. Samples were then placed in a water bath, preventing moisture or water vapor from penetrating the sample at a temperature adjusted to $50 \pm 2{ }^{\circ} \mathrm{C}$ for approximately $3 \mathrm{~h}$. This dissolved all the sugar crystals, even those that were imperceptible. The sample was allowed to cool to room temperature, stirred with a glass rod, and a small amount of honey was placed on the prism of the refractometer. The measurement was taken in quadruplicate. An Abbe refractometer equipped with a thermostat was used to determine moisture. This equipment is suitable for reading refraction values up to the fourth decimal place and calibrated with distilled water at $20^{\circ} \mathrm{C}$.

Water insoluble solids. The procedure established by the National Normalization Institute using the standard NCh3047Of.2007 (INN, 2013) was followed to determine wax particles, insect residues, plant material, and pollen. The procedure consisted in a $20 \pm 1 \mathrm{~g}$ honey sample (value of $\mathrm{m} 0$ ) dissolved in approximately $200 \mathrm{~mL}$ water at $80{ }^{\circ} \mathrm{C}$. The solution was filtered in a crucible melting pot. The filtered material was carefully washed with water at $80{ }^{\circ} \mathrm{C}$ until it was free of sugars. The assay was checked by the Mohr test. For filtering, a crucible melting pot previously filtered in an oven at $135 \pm 2{ }^{\circ} \mathrm{C}$ for $1 \mathrm{~h}$ was used. It was then cooled in a desiccator and weighed at $0.1 \mathrm{mg}$ accuracy (value of $\mathrm{m} 1$ ). The crucible melting pot with the residues of insoluble solids were dried for $1 \mathrm{~h}$ at $350 \pm 2{ }^{\circ} \mathrm{C}$, allowed to cool in the desiccator, and weighed at an accuracy of $0.1 \mathrm{mg}\left(\right.$ value of $\left.\mathrm{m}^{2}\right)$. Drying was continued until constant weight was obtained.

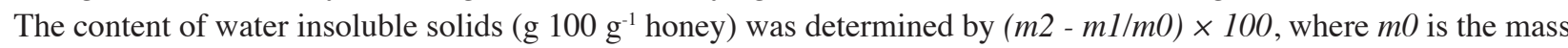
of the honey test sample $(\mathrm{g}), m 1$ is the mass of the previously prepared crucible melting pot $(\mathrm{g})$, and $m 2$ is the mass of the crucible melting pot with the residue of insoluble solids $(\mathrm{g})$.

For the Mohr test, an aliquot of the wash filtrate was taken and a phloroglucinol solution was added; this solution was mixed, a few drops of concentrated sulfuric acid were added through the side of the tube, and a color was produced at the interface if sugars were present. Washing continued until no coloration appeared.

pH. The procedure established by the National Normalization Institute using the standard NCh3019Of.2006 (INN, 2013) was followed to determine $\mathrm{pH}$. It describes the method for potentiometric determination of free acidity from the concentration of hydrogen ions in honey. It was carried out with an electrode coupled to a $\mathrm{pH}$ meter (potentiometer). This potential difference compared with a reference electrode was proportional to the difference in the concentration of hydrogen ions in both dissolutions. The $\mathrm{pH}$ meter measured this potential difference and transformed it into a $\mathrm{pH}$ scale. 
Ashes. The procedure established by the National Normalization Institute using the standard NCh3102Of.2007 (INN, 2013) was followed to determine ash content. This procedure describes the method to determine ash content, expressed in $\mathrm{g} 100 \mathrm{~g}^{-1}$ honey. The amount of ash of each sample was measured by taking 5 to $10 \mathrm{~g}$ of honey without impurities and with an accuracy of $0.001 \mathrm{~g}$ in a previously prepared crucible melting pot (weight of mass $\mathrm{m} 0$ ). Two drops of mineral-free vegetable oil were added and the sample was evaporated on a heating plate at between 350 and $400{ }^{\circ} \mathrm{C}$. The evaporated samples were taken to an electric oven preheated to $600^{\circ} \mathrm{C}$ and heated for at least $1 \mathrm{~h}$. Afterward, the crucible melting pot was cooled in the desiccator at room temperature and weighed (weight of mass $\mathrm{m} 1$ ). This procedure was repeated until constant weight was obtained.

A crucible melting pot was used, previously heated in an electric oven at between 350 and $400{ }^{\circ} \mathrm{C}$ and weighed with an accuracy of $0.001 \mathrm{~g}$ after being cooled in the desiccator at room temperature (weight of mass $\mathrm{m} 2$ ). The calculation of the ash content expressed in $\mathrm{g} 100 \mathrm{~g}^{-1}$ honey was performed by $W A=(\mathrm{ml}-\mathrm{m} 2 / \mathrm{m} 0) \times 100$, where $\mathrm{m} 0$ is the initial mass of the sample (g), $m l$ is the mass of crucible melting pot and ash residue (g), and $m 2$ is the mass of the previously prepared crucible melting pot $(\mathrm{g})$.

Electrical conductivity. The procedure established by the National Normalization Institute using the the standard NCh3064Of.2007 (INN, 2013) was followed to determine electrical conductivity. This procedure describes the method to determine electrical conductivity of a honey solution. The conductivity of honey samples was measured by taking a $20 \mathrm{~g}$ solution of each sample in $100 \mathrm{~mL}$ distilled water at a stable temperature of $20 \pm 0.5^{\circ} \mathrm{C}$. The calculation of the electrical conductivity of each solution was expressed as approximately $0.01 \mathrm{mS} \mathrm{cm}^{-1}$.

Hydroxymethylfurfural. The procedure established by the National Normalization Institute using the standard NCh3046Of.2007 (INN, 2013) was followed to determine the hydroxymethylfurfural (HMF) content. This procedure describes the method to determine the HMF content in honey by UV spectrometry. The HMF content of each sample was measured by placing a 5-g honey sample without impurities (in duplicate) in $50 \mathrm{~mL}$ beakers; $25 \mathrm{~mL}$ distilled water was added and the sample was stirred until the honey was dissolved. Some $0.5 \mathrm{~mL}$ Carrez I solution was added to each beaker and mixed, and drops of ethanol were added to suppress the foam. Each sample was quantitatively transferred to a $50 \mathrm{~mL}$ flask and filled with water. The content was stirred and filtered with Whatman $\mathrm{N}^{\circ} 2$ paper. The first $10 \mathrm{~mL}$ of filtrate was discarded and the rest was collected in a new beaker. Some $10 \mathrm{~mL}$ of filtrated material was placed in two $18 \mathrm{~mm} \times 150$ $\mathrm{mm}$ test tubes ( $5 \mathrm{~mL}$ each). A total of $5 \mathrm{~mL}$ sodium bisulfite solution was added and the absorbance at 284 (A284) and 336 $\mathrm{nm}$ (A336) was immediately measured by placing the solution in $1 \mathrm{~cm}$ cells. Afterward, $5 \mathrm{~mL}$ of distilled water was added to the other tube (sample solution to be measured) and the absorbance was measured in the same way as for the reference solution. If the absorbance of the sample solution was greater than 0.6 , it was diluted with water and the reference solution

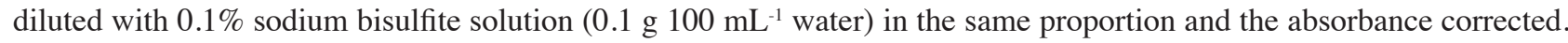
The amount of HFM (mg $\left.100 \mathrm{~g}^{-1}\right)$ in the types of honey from the absorbance data at 294 and $336 \mathrm{~nm}$ was calculated as $H M F=(A 284-A 336) \times 5 \times 14.97 /$ test portion, where A284 is absorbance measured at $284 \mathrm{~nm}, A 336$ is absorbance measured at $336 \mathrm{~nm}, 5$ is the nominal test portion $(\mathrm{g})$, test portion $(\mathrm{g})$ is the honey mass weighed on a precision balance, and 14.97 is the factor $=(126 / 16830)(1000 / 10)(100 / 5)$.

\section{Microbiological characterization}

The procedure established by the National Normalization Institute using the standard NCh3109Of.2008 (INN, 2013) was followed to determine the presence of total coliform bacteria and Escherichia coli. This procedure describes the method by the most probable number technique (MPN). The method began with the preparation of primary dilution and subsequent dilutions; the sample was shaken in such a way that the microorganisms were distributed in the most homogeneous way possible by inverting the sample container. The interval between taking the aliquot and mixing was not more than $3 \mathrm{~min}$. Subsequently, $1.0 \mathrm{~mL}$ of the test sample was taken and $9.0 \mathrm{~mL}$ diluent added. The primary solution was stirred using a rotary movement, thus obtaining $10^{-1}$. A total of $1.0 \mathrm{~mL}$ primary solution was transferred to another tube containing $9.0 \mathrm{~mL}$ sterile diluent. It was carefully mixed with a mechanical stirrer for 5 to $10 \mathrm{~s}$ to obtain a $10^{-2}$ dilution. 
The process was repeated using a $10^{-2}$ solution to obtain $10^{-3}$. Each solution was carried out in triplicate. Finally, it was necessary to conduct a presumptive test, which was performed by the inoculation of the lauryl sulphate tryptose medium (LST). To achieve this, three tubes of enrichment medium (double concentration) were taken and $1 \mathrm{~mL}$ primary dilution was transferred to each of these tubes. The abovementioned procedure was followed for each of the dilutions prepared in step 1. Finally, the grid was gently stirred to mix the sample with the culture medium, preventing the entry of air in the Durham bells. The tubes were then incubated in the oven at $35 \pm 0.5^{\circ} \mathrm{C}$ for $24 \pm 2 \mathrm{~h}$. If no gas production was observed in this period, it was incubated to complete $48 \pm 2 \mathrm{~h}$. The absence of gas in all the tubes indicated a negative presumptive test for total coliforms and E. coli.

\section{RESULTS}

\section{Determination of botanical origin}

The determination of the botanical origin of the types of honey by melissopalynological analysis allowed establishing the existence of 38 pollen types, all of them with different degrees of content in each analyzed sample (Table 1). The plant families that showed higher levels of presence in honey in the province were Boraginaceae represented by the species Echium vulgare L. (viper's-bugloss) that reached 36.5\% (Quilleco, M2), 31.3\% (Antuco, M3), and 56.7\% (Laja, M11). For Alto Biobío (M6), the Cunoniaceae family was the most representative with the species Eucryphia glutinosa (Poepp. \& Endl.) Baill. (guindo santo) reaching 56.8\%. In the commune of Los Ángeles (M1), Escalloniaceae with Escallonia spp. represented 26.0\%. Meanwhile, the Fabaceae family dominated in the communes of Los Ángeles (M1, 49\%), Tucapel (M9, 18.6\%), Nacimiento (M4,41.6\%), and Quilaco (M7, 45.8\%), which were mainly represented by the species Melilotus indicus (L.), Medicago sativa (L.), Lotus pedunculatus Cav., and Galega officinalis L. The Myrtaceae family reached $27.5 \%$ in the M5 sample (Negrete).

\section{Physicochemical parameters}

All samples analyzed in the present study showed moisture percentages between $15 \%$ and $17 \%$ (Table 2). These values comply with the parameters established by the Chilean Food Sanitary Regulations (RSA) (MINSAL, 2014) and Codex Alimentarius (2001).

Values of insoluble solids were within the ranges established by the standards (both national and international) and were less than $0.1 \%$ (Table 2). Samples from Antuco (M3), Nacimiento (M4), Negrete (M5), Alto Biobío (M6), Santa Bárbara (M8), and Tucapel (M9) had contents of water insoluble solids of $0.01 \%$, corresponding to the lowest value determined in the analysis (Table 2).

The $\mathrm{pH}$ value for the analyzed samples ranged between 3 and 4 (Table 2). The most acid honey came from Quilleco (M2) with 3.55, whereas the sample from Alto Biobío had the highest $\mathrm{pH}$ value (4.52).

The ash content values (Table 2) in all the types of honey complied with Chilean regulations. The lowest ash contents occurred in the Tucapel (M9, 0.06\%) and Mulchén (M10, 0.04\%) samples, whereas the highest contents occurred in the communes of Antuco and Nacimiento (M3 and M4, 0.29\%).

Electrical conductivity varied between $0.14 \mathrm{mS} \mathrm{cm}^{-1}$ in Mulchén (M10) and $0.57 \mathrm{mS} \mathrm{cm}^{-1}$ in Antuco (M3) and Nacimiento (M4) (Table 2). Therefore, all places of provenance exhibited values within the ranges established by the Codex Alimentarius (2001). The statistical analysis showed a direct and proportional relationship between ash content and electrical conductivity in all the evaluated honey samples with $\mathrm{R}^{2}$ equal to 0.92 .

The HMF was found in the places of provenance of Quilleco (M2), Antuco (M3), Nacimiento (M4), Negrete (M5), Alto Biobío (M6), Quilaco (M7), Santa Bárbara (M8), and Tucapel (M9) which ranged from 0.90 to $4.94 \mathrm{mg} \mathrm{kg}^{-1}$. However, three samples showed no HMF activity $\left(0.00 \mathrm{mg} \mathrm{kg}^{-1}\right)$ (Los Ángeles, M1; Mulchén, M10; Laja, M11) (Table 2).

The evaluation of microbiological activity showed no presence of $E$. coli for the 11 places of provenance in all the tested concentrations $\left(10^{-1}, 10^{-2}\right.$, and $\left.10^{-3}\right)$; there was no generation of oxygen in the Durham bells or turbidity in the culture media with the samples. 
Table 1. List of pollen types determined in the types of honey in the Biobío Province, Biobío Region, Chile. Content percentages are determined in relation to a total of 1200 pollen grains counted per sample.

\begin{tabular}{|c|c|c|c|c|c|c|c|c|c|c|c|c|}
\hline \multirow[b]{2}{*}{ Plant family } & \multirow[b]{2}{*}{ Pollen type } & \multicolumn{11}{|c|}{ Sample } \\
\hline & & M1 & M2 & M3 & M4 & M5 & M6 & M7 & M8 & M9 & M10 & M11 \\
\hline Anacardiaceae & Schinus polygamus & + & 2.8 & + & + & 1.1 & + & + & + & 4.1 & 2.3 & 5.8 \\
\hline Apiaceae & & + & 19.6 & 3.3 & 3.6 & + & + & 8.3 & 2.7 & + & + & 6.0 \\
\hline Berberidaceae & Berberis sp. & & & & & & & & 3.0 & & & \\
\hline Boraginaceae & Echium vulgare & 1.5 & 36.5 & 31.3 & 1.5 & 7.4 & 5.9 & 5.3 & 14.1 & + & 9.6 & 56.7 \\
\hline Brassicaceae & Brassica sp. & + & & & & + & & & + & 14.5 & 14.9 & + \\
\hline Convolvulaceae & Convolvulus sp. & & & 1.7 & + & & & + & + & 1.5 & 30.8 & + \\
\hline Cunoniaceae & Eucryphia glutinosa & + & 1.1 & & & & 56.8 & + & & & & \\
\hline Elaeocarpaceae & Aristotelia chilensis & + & 7.7 & + & + & + & + & 16.9 & 2.3 & & 3.6 & 3.7 \\
\hline Escalloniaceae & Escallonia sp. & 26.0 & & & & & & 6.3 & 9.4 & 26.3 & 3.9 & \\
\hline Euphorbiaceae & & & & & 18.2 & & 2.4 & & & & & \\
\hline Fabaceae & & + & 3.5 & 2.7 & 4.5 & 7.2 & + & 3.8 & 21.4 & + & 1.4 & 2.3 \\
\hline & Galega officinalis & + & + & 2.0 & & + & & 6.9 & & & & 1.4 \\
\hline & Lotus pedunculatus & + & + & 10.7 & 5.0 & 15.4 & 2.9 & 29.1 & 3.3 & 15.8 & 2.6 & 7.0 \\
\hline & Medicago sativa & + & + & 2.1 & 32.1 & 1.2 & & 6.0 & 4.7 & & 2.0 & + \\
\hline & Melilotus indicus & 49.0 & & & & & & & & 2.8 & & \\
\hline & Trifolium sp. & & & & & & & & & & 3.1 & \\
\hline & Vicia sp. & & & & & 3.5 & & & & & & \\
\hline Gentianaceae & Selliera radicans & & & & & & & & & & 1.5 & \\
\hline Gesneriaceae & Mitraria coccinea & + & & & 2.3 & + & & + & & & & \\
\hline Lardizabalaceae & Boquila trifoliolata & & & & & & & & & 16.5 & & \\
\hline Myrtaceae & & 8.3 & + & 6.9 & 5.6 & 27.5 & 1.8 & + & + & + & 8.5 & + \\
\hline Plantaginaceae & Plantago sp. & & & 1.5 & & & & & & & + & \\
\hline Poaceae & & + & 1.5 & & & & & + & + & + & & + \\
\hline Polygonaceae & & & & & & 5.1 & & 6.5 & 24.4 & & & \\
\hline Primulaceae & & & & 4.8 & 1.3 & 3.8 & & & & & & \\
\hline Proteaceae & & + & & & & + & 14.5 & + & + & & + & + \\
\hline Quillajaceae & Quillaja saponaria & + & 4.4 & + & 1.7 & + & 3.0 & 3.3 & 8.9 & + & 1.0 & + \\
\hline Ranunculaceae & & & & & 1.0 & & & & & & & \\
\hline Rhamnaceae & & & & & 1.5 & & & & & & 3.0 & \\
\hline & Retanilla stricta & & & & + & & & & & & + & \\
\hline Rosaceae & Rosa sp. & 2.0 & 3.3 & 4.9 & 6.9 & 1.8 & + & + & 1.3 & + & + & + \\
\hline & Prunus sp. & + & 5.0 & 4.9 & 2.5 & & & & + & 7.9 & + & \\
\hline & Rubus ulmifolius & + & 3.8 & + & 1.5 & & & + & 1.4 & 1.7 & + & + \\
\hline Rubiaceae & & & & & & & 3.6 & & & & & \\
\hline Salicaceae & & + & 1.7 & & & & & & & & + & \\
\hline Saxifragaceae & & 1.0 & & & & 5.5 & & 1.7 & & & 1.1 & 9.7 \\
\hline Verbenaceae & & & & & & 10.6 & & & & & & \\
\hline Vitaceae & Cissus striata & 3.9 & & + & + & & & & + & + & 1.0 & 4.0 \\
\hline
\end{tabular}

+ : Indicates the presence of the pollen type in a percentage less than $1 \%$.

\section{DISCUSSION}

\section{Determination of botanical origin}

According to the Chilean official standard to determine the botanical origin in honey, samples meeting the requirements to be considered as monofloral were those from Alto Biobío (M6, 56.8\% Eucryphia glutinosa), Los Ángeles (M1, 49.0\% Melilotus indicus), and Laja (M11,56.7\% Echium vulgare). These results have provided more comprehensive information than the findings reported by Montenegro et al. (2008), which only showed the existence of the Chilean hazelnut (Gevuina avellana) monofloral honey and the introduced alfalfa (Medicago sativa) in the Biobío Region. Our results did not concur with those indicated by these authors. However, honey samples showed $14.5 \%$ Proteaceae family as a maximum content in the M6 sample and 32.4\% Fabaceae family as the maximum content with the M. sativa pollen in the M4 sample. This allows us to corroborate that the food preferences of bees are similar in different harvest periods. Thus, during the honey 
production period of the studied samples, there was a greater diversity of plants available for the bees to sip, which is consistent with changes in the flowering periods due to the effects of climate change (Lustenhouwer et al., 2018). Monofloral types of honey of introduced species found in this study have also been described in the La Araucanía and Los Lagos Regions in addition to pollen types very common in national types of honey (Montenegro et al., 2008; Navarrete et al., 2016).

In Chile, the most desirable types of honey are those from native and/or endemic species such as Quillaja saponaria (soapbark), Eucryphia cordifolia (ulmo), Escallonia pulverulenta (madroño), G. avellana (Chilean hazelnut), and Weinmannia trichosperma (tineo) (Montenegro et al., 2008; Bridi and Montenegro, 2017). However, the monofloral honey of the species E. glutinosa (nirrhe) found in this study is still unknown and understudied; it could potentially be a product with high added value and exclusive characteristics due to its endemic origin. This could be enhanced with possible antioxidant and antimicrobial properties such as those found in other native types of honey in Chile (Montenegro et al., 2009; Bridi and Montenegro, 2017).

The species E. glutinosa belongs to the Cunoniaceae family and is one of the two species of the Eucryphia genus in Chile. The other species is E. cordifolia (ulmo), which has been studied for its melliferous attractiveness, its antimicrobial, antibacterial, antioxidant, antiproliferative, and cytotoxic properties, and because it can be used as a treatment to heal burns (Mejías and Montenegro, 2012; Schencke et al., 2016). Therefore, it is possible to make an a priori assumption that E. glutinosa (nirrhe) honey could have beneficial properties for human health due to the close phylogenetic relationship between both plant species.

In some iconic cases of honey production with unique characteristics in the world are Manuka honey (Abd El-Malek et al., 2017; Nguyen et al., 2018) and Tenerife honey (Manzanares et al., 2014). For Manuka honey, there has been a greater commercial and economic development for New Zealand growers because their honey has a high market value and there is a high demand for this product due to the medicinal properties of monofloral species native to New Zealand (Lloyd et al., 2017). Similarly, the quality and unique characteristics of Tenerife honey have led beekeepers and local authorities to create legislation to protect the designation of origin of their honey with the Royal Decree 1069/2007 (Manzanares et al., 2014). These cases would be homologous to the E. glutinosa honey and the current Chilean situation.

\section{Physicochemical parameters}

Moisture is one of the most important parameters when establishing the quality of honey and is related to the degree of maturity. Water content determines the possibility of product fermentation by promoting the proliferation of fungi and bacteria, which seriously affect its organoleptic characteristics (Navarrete et al., 2016). All types of honey contain yeast, which in the presence of sugar and optimal levels of temperature and humidity activate their metabolism. However, honey does not ferment with moisture contents less than $17.1 \%$, although the total yeast count in the sample is high. Of the total honey samples analyzed in this study, only one place of provenance (M10) had a percentage greater than $17.1 \%$ (Table 2). Despite this and including the M10 place of provenance, all samples had moisture levels within the parameters established by the Chilean Food Sanitary Regulations (MINSAL, 2004) and Codex Alimentarius (2001). Some authors have described different moisture percentages in national types of honey; Navarrete et al. (2016) indicated that polyfloral types of honey from southern Chile exhibited values from $15.57 \%$ to $16.1 \%$, which are below the mean of $16.28 \%$ in the present study.

The geographical location of apiaries greatly influences water content in honey due to the ability of the honey to absorb moisture from the environment. However, this is not the only factor related to this parameter. Variables such as initial moisture of the nectar, product handling, climatic conditions, hygroscopic nature of honey, season of the year, and degree of maturation achieved in the opercula affect the moisture levels of the final product (Tornuk et al., 2013; Missio da Silva et al., 2016). According to our results, it is possible to point out that all sampled types of honey were obtained and stored under adequate protection systems and there was no possibility of fermentation.

The content of insoluble solids in the analyzed types of honey was much lower than that established by national (MINSAL, 2004) and international (Codex Alimentarius, 2001) regulations. Therefore, honey from this geographical area complies with the quality standards for this parameter.

There are studies of South American honey indicating that the content of insoluble solids is within the norms established by the Codex Alimentarius (Almeida-Muradian et al., 2013; Vit et al., 2016). The botanical origin of the types of honey, environmental characteristics of the area where the bees sip, and the extraction and storage practices used by beekeepers 
Table 2. Physicochemical parameters of types of honey from the Biobío Province, Biobío Region, Chile, compared with the parameters established by national and international standards.

\begin{tabular}{|c|c|c|c|c|c|c|c|c|}
\hline \multirow[b]{2}{*}{ Parameter } & \multicolumn{2}{|c|}{ Standards } & \multicolumn{6}{|c|}{ Samples } \\
\hline & Nat. ${ }^{1}$ & Internat. $^{2}$ & M1 & M2 & M3 & M4 & M5 & M6 \\
\hline Moisture, $\%$ & $<18.0$ & $<20.0$ & 16.32 & 16.08 & 16.86 & 16.08 & 15.31 & 16.47 \\
\hline Insoluble solids, \% & $<1.0$ & $<0.1$ & 0.03 & 0.02 & 0.01 & 0.01 & 0.01 & 0.01 \\
\hline $\mathrm{HMF}, \mathrm{mg} \mathrm{kg}^{-1}$ honey & $\leq 40.0$ & $\leq 40.0$ & 0.00 & 0.90 & 3.07 & 1.50 & 0.90 & 4.79 \\
\hline Ashes, $\%$ & $<0.8$ & - & 0.10 & 0.16 & 0.29 & 0.29 & 0.16 & 0.23 \\
\hline $\mathrm{EC}, \mathrm{mS} \mathrm{cm}^{-1}$ & - & $\leq 0.8$ & 0.25 & 0.45 & 0.57 & 0.57 & 0.33 & 0.46 \\
\hline \multirow[t]{3}{*}{$\mathrm{pH}$} & & & 3.76 & 3.55 & 4.12 & 4.38 & 3.66 & 4.52 \\
\hline & & & \multicolumn{6}{|c|}{ Samples } \\
\hline & & & M7 & M8 & M9 & M10 & M11 & Mean \\
\hline Moisture, \% & $<18.0$ & $<20.0$ & 15.70 & 16.47 & 16.86 & 17.25 & 15.70 & 16.28 \\
\hline Insoluble solids, $\%$ & $<1.0$ & $<0.1$ & 0.03 & 0.01 & 0.01 & 0.08 & 0.02 & 0.02 \\
\hline $\mathrm{HMF}, \mathrm{mg} \mathrm{kg}^{-1}$ honey & $\leq 40.0$ & $\leq 40.0$ & 1.80 & 4.94 & 4.72 & 0.00 & 0.00 & 2.05 \\
\hline Ashes, $\%$ & $<0.8$ & - & 0.15 & 0.18 & 0.06 & 0.04 & 0.17 & 0.17 \\
\hline $\mathrm{EC}, \mathrm{mS} \mathrm{cm}^{-1}$ & - & $\leq 0.8$ & 0.36 & 0.52 & 0.17 & 0.14 & 0.29 & 0.37 \\
\hline $\mathrm{pH}$ & & & 3.75 & 3.58 & 3.65 & 3.64 & 3.70 & 3.85 \\
\hline
\end{tabular}

HMF: Hydroxymethylfurfural; EC: electrical conductivity.

'National standards (MINSAL, 2004).

${ }^{2}$ International standards (Codex Alimentarius, 2001).

are factors that directly influence the content of insoluble solids (Vit et al., 2016). This establishes that the post-harvest management of honey by the producers of the Biobío Province would be adequate and would not further influence the content of compounds classified as insoluble solids.

The $\mathrm{pH}$ is related to the content of mineral elements because it represents the level of ionized acids in a sample. Honey is generally acidic, registering pH values that vary between 2.3 and 4.5 for those of floral origin and honeydew honey (produced from myelates, which are secretions of the living parts of plants or exudates of sucking insects such as that bees sip and convert them into honey) can neutralize the acidity due to the high presence of mineral elements, providing $\mathrm{pH}$ values between 4.5 and 6.5 (Tornuk et al., 2013; Karabagias et al., 2014). In the present study, pH values were between 3.55 and 4.52, and these are within the range mentioned in the literature. Navarrete et al. (2016) established pH 3.36 and 4.26 for polyfloral types of honey in southern Chile, and these values are very similar to those found in the present study. However, this parameter is not considered by current national and international regulations as critical and indispensable for determining honey quality (Codex Alimentarius, 2001; MINSAL, 2004). The taste characteristics of honey and its antimicrobial activity is largely related to acidity, which is expressed by $\mathrm{pH}$. This aspect becomes a useful parameter to discriminate different types of honey and if they show any alterations (Karabagias et al., 2014; Ribeiro et al., 2014).

All the analyzed samples complied with the requirements of the national standard with ash contents less than $0.8 \%$. There are no ranges for this parameter in Codex Alimentarius (2001) because the information obtained from determining ash content can be acquired from the values of electrical conductivity. The abovementioned is based on studies by several authors who indicated a correlation between the content of these two parameters (Codex Alimentarius, 2001; Kaskoniene et al., 2010; Yücel and Sultanoglu, 2013; Karabagias et al., 2014). The results obtained for electrical conductivity indicated that sample M10 with the lowest ash content $(0.04 \%)$ obtained the lowest value for electrical conductivity $\left(0.14 \mathrm{mS} \mathrm{cm}^{-1}\right)$. Samples M3 and M4 had the highest ash contents $(0.29 \%)$ and showed the highest level of electrical conductivity $(0.57$ $\mathrm{mS} \mathrm{cm}{ }^{-1}$ ). Together with the statistical analysis of both factors, this validated the existence of a directly proportional correlation between both parameters.

Mineral elements found in honey are reflected in the ash content. Values are usually low and mainly determined by the nectar composition of the dominant plant species, which are affected by soil type and climate (Mejías and Montenegro, 2012). It has been possible to establish a qualitative association between variability in ash content and different botanical and geographical origins of honey (Karabagias et al., 2014). Chakir et al. (2011) points out that floral origin honey encountered in the sample ranged from $0.02 \%$ to $1.03 \%$, whereas honey produced from myelates had values greater than $1.2 \%$. All types of honey evaluated in the present study had values less than $0.29 \%$, which indicates that the 11 places of provenance are of floral origin. 
Electrical conductivity varies depending on pollen type with a greater content in the sample. This allows differentiating honey with pollen origins different from myelates (Kaskoniene et al., 2010; Karabagias et al., 2014). This information is also accurate with values found in native monofloral (E.glutinosa) and exotic (M. indicus and E. vulgare) types of honey. As indicated in the Codex Alimentarius (2001), all samples in the present study meet the international requirements for values of electrical conductivity of floral origin honey (Table 2). Chilean Food Sanitary Regulations establish acceptable quality ranges for this parameter based solely on the ash content (Codex Alimentarius, 2001; MINSAL, 2004).

The HMF is a compound that is formed by the breakdown of monosaccharides (glucose and fructose) in what is known as the Maillard reaction when heat affects the honey or when it is stored for long periods. It is therefore not found in fresh and unadulterated honey. However, its concentration after storage can increase because of temperature and $\mathrm{pH}$, making this parameter one of the most important to determine honey quality as to its freshness and whether it has been subjected to overheating (Capuano and Fogliano, 2011; Yücel and Sultanoglu, 2013; Tornuk et al., 2013). Likewise, HMF is related to diastase levels in honey because the diastase activity decreases at $27^{\circ} \mathrm{C}$ as storage time increases, although this process is accelerated by subjecting the honey to temperatures greater than $40^{\circ} \mathrm{C}$. Therefore, a good quality product is one that shows high diastase activity along with low HMF levels (Yücel and Sultanoglu, 2013).

This is consistent with the findings of the present study because all the samples had HMF concentrations within the parameters established by the Chilean Food Sanitary Regulations and Codex Alimentarius. The samples were therefore fresh honey without thermal alterations prior to packaging (Codex Alimentarius, 2001; MINSAL, 2004). The HMF values in both national and international fresh honey range approximately from 0.0 to $10 \mathrm{mg} \mathrm{kg}^{-1}$. It is quite common to find concentrations below $1 \mathrm{mg} \mathrm{kg}^{-1}$ in honey from central and southern Chile (Tornuk et al., 2013; Navarrete et al., 2016). This information is similar to the results obtained in the present study in which the HMF content ranged from 0.0 to 4.95 $\mathrm{mg} \mathrm{kg}^{-1}$ honey (Table 2).

It is very important to determine the presence of contaminating microorganisms in honey because it is food for the population and is also increasingly used for its potential antimicrobial and regenerative activity in the cosmetic and pharmaceutical industry (Schencke et al., 2016; Ramos et al., 2017). The microbiological analysis showed the absence of total coliforms and E. coli in all types of honey at the tested concentrations $\left(10^{-1}, 10^{-2}\right.$, and $\left.10^{-3}\right)$; oxygen generation in the Durham bells and turbidity in the culture media were not observed in the samples. Although bees manage to make products free of contaminating and harmful organisms that ensure the health of the hives, the deficient collection and packaging practices used by beekeepers can sometimes transfer bacteria and/or fungi to the honey (Gallez and Fernández, 2009). This situation was not observed in the analyzed samples. Finally, it is important to note that although the types of honey under study did not reflect the full spectrum of regional production, the low HMF values and low microbial activity shown in the present study are evidence of a good level of beekeeping and product processing practices.

\section{CONCLUSIONS}

The determination of the botanical origin by a melissopalynological analysis showed the participation of both native and introduced plant species. Only two samples were characterized as monofloral of the introduced species Melilotus indicus (Fabaceae) and Echium vulgare (Boraginaceae), and one sample was monofloral of the endemic species Eucryphia glutinosa (guindo santo). This means that a food product with unique characteristics in the world was identified, potentially contributing added value to this product. The other samples were polyfloral.

Physicochemical and microbiological tests allowed pointing out that all types of honey met the quality standards mentioned by national and international standards. Therefore, all types of honey of this study from the Biobío Province in the Biobío Region, Chile, complied with the sanitary studies required for their commercialization.

\section{ACKNOWLEDGEMENTS}

The authors thank the VRID associative-Universidad de Concepción project $\mathrm{N}^{\circ}$ 217.418.010-1.0 and the Fondef Project ID 19I10233. 


\section{REFERENCES}

Abd El-Malek, F.F., Yousef, A.S., and El-Assar, S.A. 2017. Hydrogel film loaded with new formula from manuka honey for treatment of chronic wound infections. Journal of Global Antimicrobial Resistance 11:171-176.

Almeida-Muradian, L.B., Stramm, K.M., Horita, A., Barth, O.M., de Freitas, A.S., and Estevinho, L.M. 2013. Comparative study of the physicochemical and palynological characteristics of honey from Melipona subnitida and Apis mellifera. International Journal of Food Science and Technology 48:1698-1706.

Barrera, D. 2017. De máximos históricos a un presente complejo: comercio exterior de la miel chilena. p. 1-10. Oficina de Estudios y Políticas Agrarias (ODEPA), Santiago, Chile.

Bridi, R., and Montenegro, G. 2017. The value of Chilean honey: Floral origin related to their antioxidant and antibacterial activities. p. 63-78. Arnaut de Toledo, V.A. (ed.) Honey analysis. IntechOpen, Rijeka, Croatia. doi:10.5772/67103.

Capuano, E., and Fogliano, V. 2011. Acrylamide and 5-hydroxymethylfurfural (HMF): A review on metabolism, toxicity, occurrence in food and mitigation strategies. Food Science and Technology 44:793-810.

Chakir, A., Romane, A., Barbagianni, N., Bartoli, D., and Ferrazzi, P. 2011. Major and trace elements in different types of Moroccan honeys. Australian Journal of Basic and Applied Sciences 5:223-231.

Codex Alimentarius. 2001. Codex standard for honey. CXS12-1981 rev. FAO/WHO Food Standards Programme, Rome, Italy.

Faegri K., and Iversen, J. 1989. Textbook of pollen analysis. Wiley, Chichester, UK.

Ferrier, P.M., Rucker, R.R., Thurman, W.N., and Burgett, M. 2018. Economic effects and responses to changes in honey bee health. Economic Research 246:1-48.

Gallez, L., and Fernández, L. 2009. Mieles del sistema serrano de Ventania: evaluación de la calidad microbiológica dentro del circuito de la planta de extracción. Revista Argentina de Microbiología 41:163-167.

Heusser, C.J. 1971. Pollen and spores of Chile: modern types of the Pteridophyta, Gymnospermae, Angiospermae. University of Arizona Press, Tucson, Arizona, USA.

INN. 2013. Normas chilenas oficiales. Miel de abejas: NCh3019Of.2006, NCh3026Of.2006, NCh2981Of.2007, NCh3046Of.2007, NCh3047Of.2007, NCh3064Of.2007, NCh3102Of.2007, NCh3109Of.2008. Instituto Nacional de Normalización (INN), Santiago, Chile.

Karabagias, I.K., Badeka, A., Kontakos, S., Karabournioti, S., and Kontominas, M.G. 2014. Characterisation and classification of Greek pine honeys according to their geographical origin based on volatiles, physicochemical parameters and chemometrics. Food Chemistry 146:548-557.

Kaskoniene, V., Venskutonis, P.R., and Ceksteryte, V. 2010. Carbohydrate composition and electrical conductivity of different origin honeys from Lithuania. Food Science and Technology 43:801-807.

Lloyd, P., Maclaren, D., Bardsley, P., and Lloyd, P. 2017. Competition in the Manuka Honey Industry in New Zealand. Department of Economics, University of Melbourne, Parkville, Victoria, Australia.

Lustenhouwer, N., Wilschut, R.A., Williams, J.L., van der Putten, W.H., and Levine, J.M. 2018. Rapid evolution of phenology during range expansion with recent climate change. Global Change Biology 24(2):534-544.

Majewski, J. 2017. Beekeeping support in the European Union countries. Scientific Papers Series Management, Economic Engineering in Agriculture and Rural Development 17(4):193-198.

Manzanares, A.B., García, Z.H., Galdón, B.R., Rodríguez, E.R., and Romero, C. 2014. Physicochemical characteristics of minor monofloral honeys from Tenerife, Spain. LWT-Food Science and Technology 55(2):572-578.

Markgraf, V., and D’Antoni,H.L. 1978. Pollen flora of Argentina: Modern pollen and spore types of Pteridophyta, Gymnospermae, and Angiospermae. University of Arizona Press, Arizona, Tucson, USA.

Mejías, E., and Montenegro, G. 2012. The antioxidant activity of Chilean honey and bee pollen produced in the Llaima volcano's zones. Journal of Food Quality 35:315-322.

MINSAL. 2004. Reglamento sanitario de los alimentos. DTO. № 977/96. Ministerio de Salud (MINSAL), División Jurídica, Santiago, Chile.

Missio da Silva, P., Gauche, C., Gonzaga, L.V., Oliveira, A.C., and Fett, R. 2016. Honey: Chemical composition, stability and authenticity. Food Chemistry 196:309-323.

Montenegro, G., Gómez, M., Díaz-Forestier, J., y Pizarro, R. 2008. Aplicación de la Norma Chilena Oficial de denominación de origen botánico de la miel para la caracterización de la producción apícola. Ciencia e Investigación Agraria 35:181-190.

Montenegro, G., Salas, F., Pena, R.C., and Pizarro, R. 2009. Antibacterial and antifungic activity of the unifloral honeys of Quillaja saponaria, an endemic Chilean species. International Journal of Experimental Botany 78:141-146.

Navarrete, C., Muñoz-Olivera, G., Wells, G., Becerra, J., Alarcón, J., y Finot, V.L. 2016. Espectro polínico y análisis fisicoquímico de mieles de la Región del Biobío, Chile. Gayana Botanica 73:268-282.

Nguyen, H.T.L., Panyoyai, N., Paramita, V.D., Mantri, N., and Kasapis, S. 2018. Physicochemical and viscoelastic properties of honey from medicinal plants. Food Chemistry 241:143-149.

Popp, J., Kiss, A., Oláh, J., Máté, D., Bai, A., and Lakner, Z. 2018. Network analysis for the improvement of food safety in the international honey trade. Amfiteatru Economic 20(47):84-98. 
Ramos, G., Sánchez, A.N., Gallaguer, S., Rodríguez, M.A., Morales, E., y Chan, M.S. 2017. Presentación de casos clínicos sobre el uso de la miel en el tratamiento de heridas. Dermatología Cosmética, Médica y Quirúrgica 15:265-271.

Ribeiro, R.O.R., Mársico, E.T., Carneiro, C.S., Monteiro, M.L.G., Conte Júnior, C., and Oliveira de Jesus, E.F. 2014. Detection of honey adulteration of high fructose corn syrup by Low Field Nuclear Magnetic Resonance (LF ${ }^{1} \mathrm{H}$ NMR). Journal of Food Engineering 135:39-43.

Schencke, C., Vasconcellos, A., Sandoval, C., Torres, P., Acevedo, F., and del Sol, M. 2016. Morphometric evaluation of wound healing in burns treated with Ulmo (Eucryphia cordifolia) honey alone and supplemented with ascorbic acid in guinea pig (Cavia porcellus). Burns and Trauma 4:25. doi:10.1186/s41038-016-0050-z.

Schifani, G., Romeo, P., Dara Guccione, G., Schimmenti, E., Columba, P., and Migliore, G. 2016. Conventions of quality consumer preference toward local honey in southern Italy. Quality-Access to Success 17:92-97.

Tornuk, F., Karaman, S., Ozturk, I., Toker, O.S., Tastemur, B., Sagdic, O., et al. 2013. Quality characterization of artisanal and retail Turkish blossom honeys: Determination of physicochemical, microbiological, bioactive properties and aroma profile. Industrial Crops and Products 46:124-131.

Velásquez, P., and Montenegro, G. 2017. Chilean endemic/native plant resources as functional and superfoods. p. 131-154. Waisundrara, V., and Shiomi, N. (eds.) Superfood and functional food. IntechOpen, Rijeka, Croatia. doi:10.5772/65749.

Vit, P., Gonzáles, I., Sorroza, L., y Pedro, S.R.M. 2016. Caracterización físicoquímica de miel de angelita Tetragonisca angustula (Latreille, 1811) producida en Esmeraldas, Ecuador. Ciencia UNEMI 9(20):77-84.

Yücel, Y., and Sultanoglu, P. 2013. Characterization of honeys from Hatay Region by their physicochemical properties combined with chemometrics. Food Bioscience 1:16-25. 